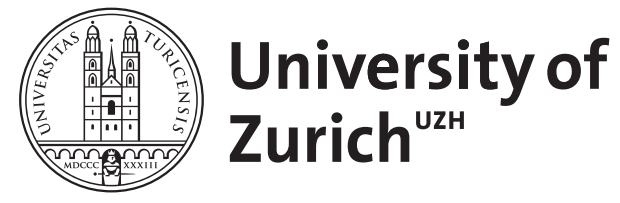

\title{
Introduction to the Corporate Governance of Religion
}

\author{
Rost, Katja
}

DOI: https://doi.org/10.1002/9781118900772

Posted at the Zurich Open Repository and Archive, University of Zurich

ZORA URL: https://doi.org/10.5167/uzh-133251

Book Section

Published Version

Originally published at:

Rost, Katja (2017). Introduction to the Corporate Governance of Religion. In: Scott, Robert A; Buchmann, M. Emerging Trends in the Social and Behavioral Sciences: An Interdisciplinary, Searchable, and Linkable Resource. Hoboken: Wiley-VCH, 1-10.

DOI: https://doi.org/10.1002/9781118900772 


\title{
Introduction to the Corporate Governance of Religion
}

\author{
KATJA ROST
}

\begin{abstract}
Stationed at the border between the past and the present, the corporate governance of religion is concerned with the governance mechanisms by which religious organizations are controlled and directed. Building on similarities between contemporary organizations and their predecessors in Roman Catholic monasticism, this essay illustrates that studying the past can be of enormous benefit. It allows us to see familiar problems in a new light: for example, bureaucratic rules-nowadays no longer linked to efficiency-that emerged in Catholic orders and enabled organizational learning, innovations, and survival in uncertain environments. The study of the past is also an appreciation for the kind of governance mechanisms that have staying power: Catholic orders can be viewed as pioneers of corporate governance and show what kind of governance is suitable to reduce agency problems. Finally, when abstract organizational theories are presented in a historical context, it makes them more palatable, more understandable, and more interesting: the theory of the optimal colocation of decision rights within the specific knowledge framework of organizations is supported in Catholic orders. They decentralize their local communities the higher the ratio of credence goods produced, and centralize their local communities the higher the ratio of search/experience goods produced.
\end{abstract}

\section{INTRODUCTION}

The secularization thesis-in the last century widely perceived as an irrevocable fact-has these days become highly disputed (Iannaccone, 1998; Mart1, 2014). The recognition of the continued relevance of religion has reawakened interest in this subject. While the sociology of religion (Davie, 2013; Johnstone, 2015) and the economics of religion (Iannaccone, 1998; Nelson, 2014) are well established fields in sociology and economics, organizational research has for a long time refrained from a stronger focus on studies of religion. The corporate governance of religion is a relatively new emerging field concerned with the governance mechanisms by which religious organizations are controlled and directed, including,

Emerging Trends in the Social and Behavioral Sciences.

Robert Scott and Marlis Buchmann (General Editors) with Stephen Kosslyn (Consulting Editor).

(C) 2017 John Wiley \& Sons, Inc. ISBN 978-1-118-90077-2. 
for example, the distribution of decision rights, responsibilities and rules in religious organizations, the instruments for selection and election of leaders for interest alignment and the monitoring of actions, and the robustness of these mechanisms in the context of social, regulatory, and market change. This essay aims to show that a comparison between the governance mechanisms of religious organizations and contemporary organizations may be fruitful. It cannot consider all forms of religious organizations. While the most basic forms of communities of believers comprise religious movements (e.g., the early Christian movement), denominations (e.g., the Roman Catholic Church), sects, and cults, the essay concentrates on Roman Catholic monasticism. This rather narrow focus is caused by the fact that evidence on other forms of religious organizations is still rare.

\section{ROMAN CATHOLIC MONASTICISM AS A PREDECESSOR OF MODERN ORGANIZATIONS}

In the Western world, the Roman Catholic Church is the oldest and most enduring organization (Ekelund, Hébert, \& Tollison, 1989; Ekelund, Tollison, Anderson, Robert, \& Davidson, 1996). The economics of religion has viewed the Roman Catholic Church as a monopolistic "multidivisional" firm. This type of firm is characterized by a central office that not only controls the most relevant financial allocations and has the last word on strategic planning but also allows its divisions a high degree of autonomy in matters of operation. Around 500 A.D. the first Catholic orders were established (Schmidtchen \& Mayer, 1997). Rivalry and what can be described as "product differentiation" led to the emergence of numerous Catholic orders (Ehrmann, Rost, \& Inauen, 2013). A Catholic religious order is an organization, recognized by the Roman Catholic Church, whose members strive to achieve a common purpose through formally dedicating their life to God. Catholic orders are parent institutions composed of local communities, in most cases of monasteries. These local communities are embedded in a hierarchical structure of geographic regions (e.g., congregations or provinces), the order (e.g., headed by a superior general or a confederation), and the Holy See. Religious orders are regulated by Church law, by the religious rule they have adopted, and by their own norms (Rost, Inauen, Osterloh, \& Frey, 2010).

Religious orders can be viewed as sub-brands of the Roman Catholic Church and analyzed as intra-brand competition within the Roman Catholic Church distribution system (Ehrmann et al., 2013). The Roman Catholic Church entered into license agreements with religious orders (Davidson, 1995; Schmidtchen \& Mayer, 1997). To get licensed by the 
Church, religious orders had to estimate their profitability or to justify their legitimacy. Under the Roman Catholic Church's umbrella brand, religious orders occupy niche markets by offering specialized products and services under a sub-brand, and use identifiable brand names that help to assure the customer of uniform product quality (Brickley \& Dark, 1987). For example, some religious orders strictly isolate their members from the outside world (e.g., Carthusians and Cistercians), whereas other religious orders require their members to interact with the secular world by teaching (e.g., Jesuits and Salvatorians), missionary work (e.g., Divine World Missionaries and White Fathers), or social work (e.g., Franciscans and Camillians) (Schwaiger \& Heim, 2008). Put differently, the various religious orders are something like McCafe and the Big Mac under McDonalds' umbrella brand.

In many respects, Roman Catholic monasticism can be seen as a precursor of capitalism with its underlying governance structures, incentive systems, and monitoring instruments. For example, Ekelund et al. (1996) use the term franchise system to describe the governance structure of the Medieval Church. An article by Davidson (1995) develops this idea further by showing that the Cistercian Order can be seen as a vertically integrated downstream "franchise system" of the medieval Roman Catholic Church. Also, the analysis of the concept of purgatory within the medieval Church has been identified as an innovative incentive system to appropriate rents (Le Goff, 1986; Schmidtchen \& Mayer, 1997), or the analysis of medieval judicial ordeals revealed that it was an accurate monitoring instrument to test accused criminals' guilt and innocence (Leeson, 2012). Furthermore, as Weber $(1958,1973)$ points out, it was in monasteries where work first assumed an ascetic value. Through the process of rationalization, medieval monasteries were rapidly transformed into major institutions of capitalist enterprise (Kieser, 1987). The income of monasteries came from general commerce, which included selling their own crops, fish, game, and grain, as well as books, holy water, and candles. It also came from leasing, imposing market dues, and collecting penalties, fees for juridical services, and toll charges for rivers and country roads (Smith, 2009). Indeed, medieval monasteries can be viewed as "the most efficient production organizations of that time" (Kieser, 1987, p. 104). Catholic orders with their monasteries became enormously rich through their rational labor organization and their work morale and, as a result and as illustrated in Figure 1, spread from Europe throughout the world in a short period (Rost \& Grätzer, 2014; Schmiedl, 2011). The resulting wealth was a significant reason why governance mechanisms became this important: it was not uncommon for abbots and even entire monasteries to live a life of luxury. 


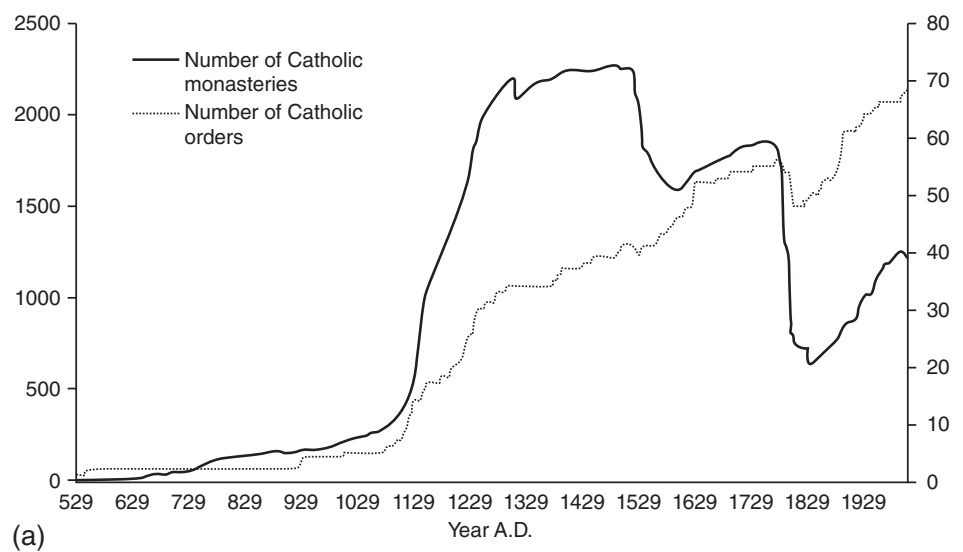

(1)

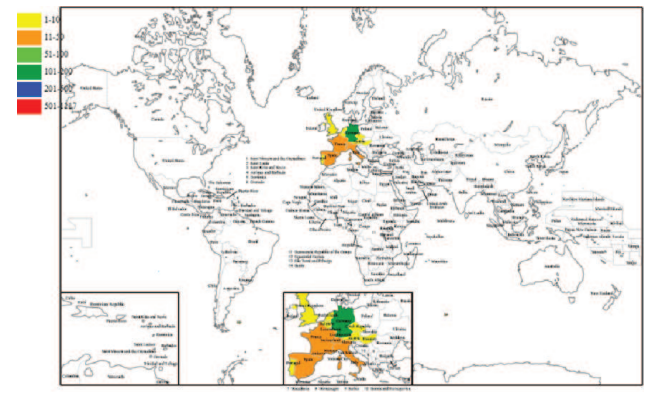

(4)

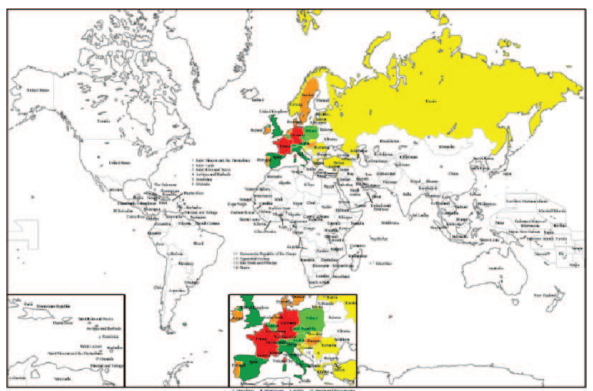

(3)
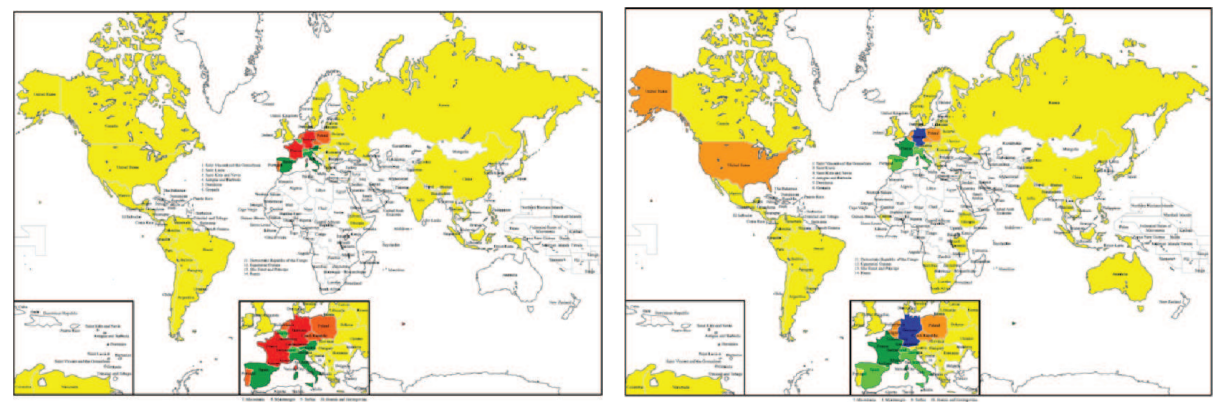

(5)

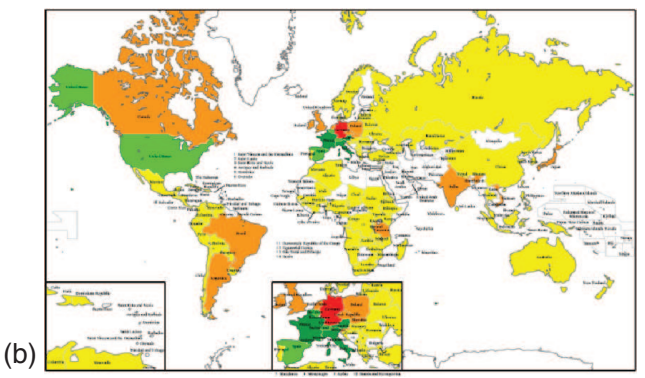


Figure 1 (a) The worldwide diffusion of Roman Catholic monasticism over time. (b) (From the top left to the bottom right): Number of Catholic orders and monasteries over (1) 500-1000 A.D. (228 monasteries in 13 countries); (2) 1001-1500 A.D. (2771 monasteries in 31 countries); (3) 1501-1700 A.D. (1909 monasteries in 59 countries); (4) 1701-1900 A.D. (1009 monasteries in 69 countries); (5) 1901-2012 A.D. (1746 monasteries in 115 countries). Data: Census of all ever existing 4342 Catholic monasteries of 81 Catholic orders.

\section{WHAT IS THE VALUE OF STUDYING ROMAN CATHOLIC MONASTICISM?}

The former arguments illustrate that Roman Catholic monasticism and contemporary organizations have many similarities. A comparison between the governance mechanisms of both organizational forms may be fruitful. However, one could argue that, by its nature, the study of Roman Catholic monasticism (and also of other forms of religious organizations) is necessarily stationed at the border between the past and the present, whereas organizational studies-mostly conceived as the study of contemporary organizations - is forward looking. Is it reasonable, therefore, for organizational scholars to concentrate on past triumphs and failure? It depends. Merely looking backward for nostalgia's sake is of benefit for historians, but it is of no particular benefit for organizational scholars. Of great benefit for organizational scholars is, however, a keener understanding of the governance mechanisms used in contemporary organizations by exposure to the shortcomings and the advantages of past governance mechanism used in religious organizations. In the following, three particular benefits of studying the past will be illustrated by giving examples on the corporate governance of Roman Catholic monasticism and by comparing it with contemporary organizations. It will be demonstrated that studying the past first allows us to see familiar situations or problems in a new light. Second, studying the past can give us appreciation for the kind of governance mechanisms that have staying power. Third, it can make abstract organizational theories more palatable, more understandable, and more interesting (Ekelund \& Hébert, 2013).

\section{FAMILIAR PROBLEMS IN A NEW LIGHT: THE VALUE OF BUREAUCRATIC RULES FOR ORGANIZATIONAL LEARNING}

Studying the past allows us to see familiar problems in a new light. Both monasteries and contemporary organizations need to secure an economic 
foundation and need to deal with environmental complexity, for example, due to technological shift, political upheaval, or differences in cultures and norms within the organization. Monasteries impressively demonstrate that organizational rules, as a primary feature of bureaucracy, are the main enabler for organizational efficiency, for learning, and for survival under environmental complexity. This is surprising because "nowadays the term bureaucracy, at least in everyday language, is no longer linked to 'rationality' or 'efficiency', but to cumbersome, overregulated, and impersonal processes that individuals are forced to adhere to" (Beck \& Kieser, 2003, p. 794). This neglect also becomes reflected in research: organizational rules were a recurrent theme in the classical work of organizational scholars (Blau, 1955; Cyert \& March, 1963; Weber, 1964 [1921]), but in the recent past we find only a few studies explicitly dealing with organizational rules. Monasteries shed new light on the importance of organizational rules in contemporary organizations by showing that they help organizations to improve efficiency, to innovate, and to deal with heterogeneous problems and complexity.

History reveals that it was in the monastery where the rule-following bureaucracy emerged as a consequence of the process of rationalization (Weber, 1958, 1973). Around 323 A.D., the Egyptian Saint Pachomius set out to design rules for all ascetic life (Kieser, 1987; Treiber \& Steinert, 1980) with the intention to bring together individual ascetics who did not have the physical ability or skills to live a solitary existence in the desert. The rule of Pachomius changed the existing view on work by stating that monks have the duty to work because labor is the basis for the monks' subsistence and for charity, and thus enables them to live in the Spirit of Christ (Kieser, 1987). In the following centuries, a number of religious movements, which later became Catholic orders, were founded. Following Pachomius's example, they managed their affiliated monasteries by rules. "Though their Rules varied considerably in details, the main themes remained the same: the design of the monastic buildings, religious ceremonies, labor, and work organization" (Kieser, 1987, p. 106).

For example, in the sixth century, Benedict of Nursia's Rule-which became the most influential one-was written down. The introduction of bureaucratic rules and the redefinition of labor within these rules explain why the early medieval monastery can be seen as a "perfect laboratory for the production of an industrious, reliable person" (Kieser, 1987, p. 108; Treiber \& Steinert, 1980). In Benedict's Rule, for example, directives contained construction plans of a monastery such as the arrangement of water, the mill, and various crafts within the enclosure to avoid the monks' straying outside of its bounds; a sophisticated forecasting rule for the food needed, which was concerned with precise enumeration of the goods, what to do to 
secure deliveries in case of shortfalls, and how to distribute the food within the monastery; or concepts of timing to ensure that everything would be fulfilled at its proper time. According to Gimpel (1976), a "blind Cistercian monk moving into any of the monasteries would instantly have known where he was. In certain ways, the discipline imposed by Saint Bernard on his monks - the rigid timetable, the impossibility of deviating from the Rule without facing punishment-rings to mind the work regulations that Henry Ford imposed on his assembly lines."

Because of this rational organization, medieval monasteries developed innovative management, production, and architectural methods such as the art of planting orchards, improving fruit trees through grafting, breeding of livestock, wine and beer making, and developing methods for heating and sanitation (Kieser, 1987; McGrath, 2005, 2007; Melville, 2012). Handwriting became a crucial art to provide blueprints of the monastic rule in order to socialize new members in far-flung monasteries (Kieser, 1987). "This, in turn, led to a differentiation of artistic and scientific professions within the monastery and to a concentration of research and teaching in monastic schools" (Kieser, 1987, p. 114). For example, the Franziscans became one of the most influential late-medieval financial experts (Todeshini \& Melucci, 2009). They created an economic key vocabulary in order to distinguish between "good" fluid capital and "bad" fixed capital, or the Franziscan Luca Pacioli wrote the first teaching book for double-entry bookkeeping (Kehnel, 2012). Because of bureaucratic rules in medieval monasteries, the process of rationalization thus proceeded at a much faster rate than in other social institutions of this time.

Organizational rules also explain why monasteries of some Catholic orders survived longer, and here, in particular, under complexity or in times of uncertainty (Rost \& Grätzer, 2014). In general, each founder of a Catholic order set up his own monastic rule. Also, the adoption of an already existing rule to a new community was possible (Melville, 2012). Rost and Grätzer (2014) used a sample of 4606 monasteries of 89 Catholic Orders over a period of 1483 years and showed that, after 500 years, monasteries managed by a large number of rigorous rules existed with a $20 \%$ higher likelihood as compared to entities managed by a smaller number of rules and more fuzzy definitions of problem areas. The results further indicate that a large number of rigorous rules, in particular, improve organizational survival under complexity and in times of uncertainty, that is, rigorous rules are, in particular, helpful to manage entities of large and international diversified orders, to manage geographically distant monasteries, or to extenuate negative or positive spillover effects in the environment. According to theories of organizational learning, organizational rules are repositories of organizational knowledge and competence (Kieser, Beck, \& Tainio, 2001; 
March, Schulz, \& Zhou, 2000). Organizations learn from experiences, and learning results in formal rules. Formal rules help the organization to avoid current and anticipated problems by abiding by the rules. Rules allow the transfer and accumulation of organizational experiences over time and enable organizational members to solve problems in a highly flexible manner (Beck \& Kieser, 2003). From this point of view, "organizational rule production is driven by experiences with organizational problems (...) A rich supply of problems supports more intense rule production than a meager supply of problems" (Schulz, 1998, p. 852). It follows that governance by bureaucratic rules helps organizations to deal with heterogeneous problems and complexity.

\section{GOVERNANCE WITH STAYING POWER: THE SOLUTION OF AGENCY PROBLEMS IN CATHOLIC ORDERS}

What separates good organizational design from bad organizational design? Why did certain types of Catholic orders survive until the present long after their emergence centuries before? Traditional organizational studies have little time and no data for such issues, yet the answers have an enormous impact on organizational theory and governance alternatives for contemporary organizations. For example, in the last decades the corporate governance of contemporary organizations has often been criticized for excessive manager compensation and fraudulent bookkeeping (Jensen, Murphy, \& Wruck, 2004). It became clear that the exclusive trust in external control mechanisms, as recommended in agency theory (Jensen \& Meckling, 1976; Jensen \& Murhpy, 1990), cannot prevent excessive risk taking and the abuse of power in a satisfying way (Frey \& Osterloh, 2005). The weaknesses in current corporate governance practice suggest that it may be useful to approach these issues from alternative perspectives. Catholic orders can be viewed as pioneers of governance, and demonstrate that alternative models may be more suitable to reduce agency problems. The great economic success of numerous monasteries in medieval times led to the temptation of misuse (Rost et al., 2010). There exist also more recent historical examples about financial scandals in the church. In the early 1990s, the Church of England lost hundreds of millions of pounds in reckless property speculation by Church Commissioners, who were established as a consequence of post-war development of London and controlled the church's investments (Lovell, 1998). As a reaction, sophisticated governance systems were established within religious orders. A fast growing literature has studied how the different Catholic orders have solved their agency problems.

First, monasteries are extremely robust organizations, and agency problems are relatively small. For example, Rost et al. (2010) analyze 
all Benedictine monasteries that ever existed in Baden-Württemberg, Bavaria and German-speaking Switzerland. The findings indicate that, on average, monasteries survived 460 years, and only a quarter of the monasteries studied were unable to survive because of agency problems. Feldbauer-Durstmüller, Sandberger, and Neulinger (2016) replicate these findings by analyzing all Benedictine monasteries in Austria. The average lifespan of monasteries amounts to 558 years; only 3\% of the monasteries studied were unable to survive as a result of agency problems.

Second, Catholic orders developed efficient governance mechanisms over time to solve agency problems. For example, Inauen, Rost, Osterloh, and Frey (2010) study the 896-year-old Benedictine monastery of Engelberg and analyze whether monastic corporate governance prevents agency problems. They searched the historical biographies of Engelberg to make a distinction between "good" and "poor" abbots. Words and phrases such as "incompetent", "dissipation of commodities", "not up to his job", or "irritating" were classified as poor performance. Phrases such as "exemplary", "energetic", or "outstanding" indicate good leadership. "Good" abbots have an average tenure of 19.44 years, whereas "poor" abbots have an average tenure of only 7.54 years. Thus, poor monastic leaders were not able to install themselves at the top of the monastery, even though they are essentially elected for life. The monastic structures facilitate the dismissal of poor abbots because of two mechanisms: external visitation, that is, the regular evaluation of the monastery by the umbrella organization to detect irregularities and to support monasteries in trouble; and internal pressure because an abbot largely depends on the goodwill of his convent. In line with these arguments, the results show that only $11 \%$ of the "good" abbots were not democratically elected, that is, their election was externally manipulated, whereas $67 \%$ from the abbots associated with agency problems were not democratically elected. Second, only $6 \%$ of the "good" abbots had a poor or inconspicuous track record, while $79 \%$ of the poorly performing abbots had a poor or inconspicuous track record.

Third-even though the governance mechanisms between the various Catholic orders largely differ-all Catholic orders build on the interplay between internal and external control mechanisms. For example, Benedictine monasteries build on strong internal control through a common value system, careful selection, socialization, participation, and monitoring and backed up their internal arrangements with external arrangements, for examle, periodical monitoring or jurisdiction (Dobie, 2015; Feldbauer-Durstmüller et al., 2016; Inauen et al., 2010; Rost et al., 2010). Internal control was complemented by external control mechanisms. Accounting and accountability were an essential component in the life of 
a healthy Benedictine monastery (Dobie, 2015). Knowledge of the financial transactions of a house was extended beyond the immediate participants to the wider monastic community. The process of visitation can be regarded as an early attempt at quality control. The chapters was an important instrument for the dissemination of improved accounting practices. In contrast to the Benedictines, Dominicans do not have the obligation of the stabilitas loci and the activities of the monasteries are largely outward looking. The analysis nevertheless reveals similar governance mechanisms as used by the Benedictines (Wirtz, 2016; Wirtz, Paulus, \& Charlier, 2012; Wirtz, Paulus, \& Charlier, 2013). For example, Dominicans have always devoted a lot of time to regular discussions to socialize their members. They developed democratic practices which are reflected in the regular holding of deliberative bodies at different levels (monastery, province, and order), in the election and the regular rotation of "top managers", in the limited tenure of elected persons, or in the general chapter, which covers the whole order and has a legislative function because it can amend the constitutions. Finally, also the Jesuits use a combination of internal and external control mechanisms (Wirtz, 2014). What fundamentally distinguishes the Jesuit governance from those of other religious orders is that the Jesuits elect the Superior General, who directs the Jesuits for life because his authority will be greater if he cannot be changed, because he will be better known by all, and because he has experience in the role. However, the very strong authority of the Superior General interacts with an equally strong authority from the community. The community is represented by delegates at all levels of the congregations (provincial and general). The community does elect the Superior General, but the community works with him as an equal force when it concerns important questions other than the election. In other words, the Jesuit governance builds on an equal power relationship between the "body" and the "head".

Insight into Abstract Theories: Securing Unique Knowledge by Colocation of Decision Rights

When abstract organizational theories are presented in a historical context, it makes them more palatable, more understandable, and more interesting. For example, in general, organizations face the problem of controlling the actions of their branch offices to ensure the continued value and uniqueness of their trademark. For the central company, that is, the headquarters, the question arises of how many decision rights and how much monitoring authority should be maintained to assure product quality within its local branches (Fama \& Jensen, 1983). To answer this question, Jensen and Meckling (1995) 
make a distinction between specific and general knowledge. They define specific knowledge as knowledge that is costly to transfer among agents, and general knowledge as knowledge that is easy and cheap to move. Logically, two ways for the colocation of knowledge and decision rights can be conceived. One is to move the knowledge to those with the decision rights; the other is to give the decision rights to those who have the knowledge. Total organizational costs are the sum of the costs due to lack of knowledge and the costs due to the wrong use of information advantages. It depends on the shape of both marginal costs curves whether more centralization or more decentralization is appropriate.

Ehrmann et al. (2013) test this theory with a sample of 114 local communities of 20 religious orders of the Roman Catholic Church. Religious orders are viewed as sub-brands of the Roman Catholic Church and their local communities as local branches. Ehrmann et al. (2013) posit that the production of all goods with observable characteristics, that is, of search/experience goods (for example such products as beer, herbs, farming, mission, or solidarity with the poor), should be organized centrally because the knowledge involved is easily available higher in the hierarchy of the religious order. Vice versa, all credence goods (e.g., salvation goods like contemplation, catechesis, saints, afterlife, or prayers) should be decentralized because it requires specific knowledge, which is costly to transfer among agents. The empirical findings give support for the hypothesis by showing that the religious orders centralize their local communities the higher the ratio of search/experience goods produced, and decentralize their local communities the higher the ratio of credence goods produced.

\section{OUTLOOK}

Studies on the corporate governance of religion promise to enhance organizational studies by exploring how culture more broadly, whether through religion or morals, affects the design and control mechanisms in organizations, by showing how governance mechanisms in organizations can be modified to address questions about norms, values, and social capital, or by generating information about governance mechanisms in "nonmarket" organizations. A lot of research is still missing in the field. First, knowledge on forms of religious organizations other than Roman Catholic monasticism, including other denominations, religious movements, sects, and cults, is necessary to generalize findings about governance mechanisms in order to compare alternative forms of governance mechanisms or to understand how culture and time affect governance mechanisms. Second, while a qualitative design is helpful to understand the historical feature of corporate governance, large-scale quantitative evidence is more suitable to test the validity 
of these features for social sciences. Large-scale quantitative evidence is still rare in the field. Finally, current research focuses on a selective choice of organizational theories. A variety of organizational concepts have their early beginnings in religious organizations and could be tested. For example, organizational diversity started in religious organizations because being a nun was one of the few "occupations" available to women in the Middle Ages. Religious organizations offer an excellent starting point for neo-institutional theories because, during their history, these organizations were exposed to different institutional settings including changes in state borders, changes in dynasties, governments, popes, and, thus, changes in institutional quality. Religious organizations allow us to study changing views on organizational legitimacy: even though charity is a central topic in all these organizations, it has been implemented very differently because religious organizations are also answers to the varying needs of their times. Finally, theories of radical paradigmatic change could be tested because religious organizations survived, were founded, or died out in times of transition from a paradigm in crisis to a new one, from which a new tradition of normal science emerged.

\section{REFERENCES}

Beck, N., \& Kieser, A. (2003). The complexity of rule systems, experience and organizational learning. Organization Studies, 24(5), 793-814.

Blau, P. M. (1955). The dynamics of bureaucracy. New York, NY: Random House.

Brickley, J., \& Dark, F. (1987). The choice of organizational form: The case of franchising. Journal of Financial Economics, 18, 401-420.

Cyert, R., \& March, J. G. (1963). A behavioral theory of the firm. Englewood Cliffs, NJ: Prentice Hall.

Davidson, A. B. (1995). The medieval monastery as franchise monopolist. Journal of Economic Behavior and Organization, 27(1), 119-128.

Davie, G. (2013). The sociology of religion: A critical agenda. London, England: Sage.

Dobie, A. (2015). The role of the general and provincial chapters in improving an enforcing accounting, financial and management controls in Benedictine monasteries in England 1215-1444. The British Accounting Review, 47, 142-158.

Ehrmann, T., Rost, K., \& Inauen, E. (2013). Location of decision rights in catholic religious orders. Managerial and Decision Economics, 34(1), 29-39.

Ekelund, R. B., \& Hébert, R. F. (2013). A history of economic theory and method. Longrove, IL: Waveland Press.

Ekelund, R. B. J., Hébert, R. F., \& Tollison, R. D. (1989). An economic model of the medieval church: Usury as a form of rent seeking. Journal of Law, Economics, and Organization, 5(2), 307-331.

Ekelund, R. B., Tollison, R. D., Anderson, G. M., Robert, F., \& Davidson, A. B. (1996). Sacred trust: The medieval church as an economic firm. New York, NY: Oxford University Press. 
Fama, E., \& Jensen, M. C. (1983). Agency problems and residual claims. Journal of Law and Economics, 26, 327-349.

Feldbauer-Durstmüller, B., Sandberger, S., \& Neulinger, M. (2016). Sustainability for centuries - Monastic governance of Austrian Benedictine Abbeys. European Journal of Management, Available at SSRN: https: / / ssrn.com/abstract=2101571.

Frey, B. S., \& Osterloh, M. (2005). Yes, managers should be paid like bureaucrats. Journal of Management Inquiry, 14(1), 96-111.

Gimpel, J. (1976). The medieval machine: The industrial revolution of the middle ages. London, England: Penguin Books.

Iannaccone, L. R. (1998). Introduction to the economics of religion. Journal of Economic Literature, 36(3), 1465-1495.

Inauen, E., Rost, K., Osterloh, M., \& Frey, B. S. (2010). Back to the future: A monastic perspective on corporate governance. Management Revue, 21(10), 38-59.

Jensen, C. M., \& Meckling, H. W. (1976). Theory of the firm: Managerial behavior, agency costs and ownership structure. Journal of Financial Economics, 3(4), 305-360.

Jensen, M. C., \& Meckling, W. H. (1995). Specific and general knowledge, and organizational structure. Journal of Applied Corporate Finance, 8(2), 4-18.

Jensen, C. M., \& Murhpy, J. K. (1990). Performance pay and top-management incentives. The Journal of Political Economy, 98(2), 225-264.

Jensen, M.C., Murphy, K.J., \& Wruck, E.G. (2004). Remuneration: Where we've been, how we got to here, what are the problems, and how to fix them. ECGI Working Paper Series in Finance, No. 44-2004, July 2004.

Johnstone, R. L. (2015). Religion in society: A sociology of religion. London, England: Routledge.

Kehnel, A. (2012). Not Macht Erfinderisch: Denkanstöße Zur Franziskanischen Armut Als Unternehmens- Und Wirtschaftsprinzip. In H.-D. Heimann, A. Hilsebein, B. Schmies \& C. Stiegemann (Eds.), Gelobte Armut: Armutskonzepte Der Franziskanischen Ordensfamilie Vom Mittelalter Bis in Die Gegenwart (pp. 233-240). Paderborn, Germany: Ferdinand Schöningh.

Kieser, A. (1987). From asceticism to administration of wealth. Medieval monasteries and the pitfalls of rationalization. Organization Studies, 8(2), 103-123.

Kieser, A., Beck, N., \& Tainio, R. (2001). Rules and organizational learning. The behavioral theory approach. In M. Dierkes, A. A. Berthoin, J. Child \& I. No (Eds.), Handbook of organizational learning $\mathcal{E}$ knowledge (pp. 598-623). Oxford, England: Oxford University Press.

Le Goff, J. (1986). The birth of purgatory. Chicago, IL: University of Chicago Press.

Leeson, P. T. (2012). Ordeals. Journal of Law and Economics, 55(3), 691-714.

Lovell, T. (1998). Number One Millbank: The financial downfall of the church of England. London, England: HarperCollins Publishers.

March, J. G., Schulz, M., \& Zhou, X. (2000). The dynamics of rules. Studies of change in written organizational codes. Stanford, CA: Standford University Press.

Martı, G. (2014). Present and future scholarship in the sociology of religion. Sociology of Religion, 75, 503-510.

McGrath, P. (2005). Thinking differently about knowledge-intensive firms: Insights from early medieval Irish monasticism. Organization, 12(4), 549-566. 
McGrath, P. (2007). Knowledge management in monastic communities of the medieval Irish Celtic Church. Journal of Management History, 13(2), 211-223.

Melville, G. (2012). Die Welt Der Mittelalterlichen Klöster. Geschichte Und Lebensformen. München, Germany: C. H. Beck.

Nelson, R. H. (2014). Economics as religion: From Samuelson to Chicago and beyond. University Park: Penn State Press.

Rost, K., \& Grätzer, G. (2014). Multinational organizations as rule-following bureaucracies - The example of catholic orders. Journal of International Management, 20, 290-311.

Rost, K., Inauen, E., Osterloh, M., \& Frey, B. S. (2010). Corporate governance: What can stock corporations learn from monasteries? Journal of Management History, 16(1), 90-115.

Schmidtchen, D., \& Mayer, A. (1997). Established clergy, friars and the pope: Some institutional economics of the medieval church. Journal of Institutional and Theoretical Economics, 153, 122-149.

Schmiedl, J. (2011). Orden Als Transnationale Netzwerke Der Katholischen Kirche. In I. F. E. Geschichte (Ed.), Europäische geschichte online (. Mainz: http://www. ieg-ego.eu/de/threads / europaeische-netzwerke/christliche-netzwerke/joachimschmiedl-orden-als-transnationale-netzwerke-der-katholischen-kirche).

Schulz, M. (1998). Limits to bureaucratic growth: The density dependence of organizational rule births. Administrative Science Quarterly, 43, 845-876.

Schwaiger, G., \& Heim, M. (2008). Orden Und Klöster: Das Christliche Mönchtum in Der Geschichte (Vol. ,3 ed.). München, Germany: Beck-Verlag.

Smith, N. (2009). The economics of monasticism. Fairfax, VA: George Mason University. Todeshini, G., \& Melucci, D. (2009). Franciscan wealth: From voluntary poverty to market society. Bonaventure, NY: Franciscan Institute Publications.

Treiber, H., \& Steinert, H. (1980). Die Fabrikation Des Zuverlässigen Menschen. Uber Die 'Wahlverwandtschaft' Von Kloster - Und Fabrikdisziplin. München, Germany: Heinz Moos.

Weber, M. (1958). Wirtschaftsgeschichte. Abriss Der Universalen Sozial-Und Wirtschaftsgeschichte (Vol. ,3 ed.). Berlin, Germany: Duncker and Humblot.

Weber, M. (1964 [1921]). Wirtschaft Und Gesellschaft: Grundriss der verstehenden Soziologie. Köln, Germany: Mohr.

Weber, M. (1973). Gesammelte Aufsätze Zur Wissenschaftslehre. Tubingen, Germany: J. C. B. Mohr.

Wirtz, P. (2014). Governance and missionary effectiveness of the Company of Jesus: Lessons from an extended theory of governance. HAL, hal-00974337.

Wirtz, P. (2016). The long history of western religious orders: What can we learn about (good) governance practices from monasticism and mendicant orders? Working Paper.

Wirtz, P., Paulus, O., \& Charlier, P. (2012). Le Secret D'une Organisation Qui Dure: La Gouvernance Cognitive Des Dominicains. In I. Barth (Ed.), Management et religions (pp. 121-138). Paris: Editions EMS.

Wirtz, P., Paulus, O., \& Charlier, P. (2013). Au-Delà Des Théories : Leçons De La Gouvernance Des Dominicains. Economies et Societes, 22, 147-179. 


\section{KATJA ROST SHORT BIOGRAPHY}

Katja Rost is Professor of sociology at the University of Zurich. She studied sociology and completed her $\mathrm{PhD}$ and Habilitation degrees in management and organizational studies. Before moving to the University of Zurich, she was an Assistant Professor for organizational sociology at the University of Mannheim, and a Full Professor for management at the Friedrich Schiller University, Jena. Her research focuses on economic and organizational sociology, for example, on corporate governance in contemporary organizations and on the governance mechanisms in Catholic orders.

\section{RELATED ESSAYS}

Lived Religion (Sociology), Nancy T. Ammerman

Trends in Religiosity and Religious Affiliation (Sociology), Kevin J. Christiano Institutional Change in American Religion (Sociology), Casey Clevenger and Wendy Cadge

Trust and Economic Organization (Sociology), Karen S. Cook and Bogdan State

Stability and Change in Corporate Governance (Sociology), Gerald F. Davis and Johan S. G. Chu

The Sociology of Religious Experience (Sociology), Douglas Porpora

Religion (Anthropology), Benjamin Grant Purzycki et al.

The Institutional Logics Perspective (Sociology), Patricia H. Thornton et al. 